\author{
Ks. Leszek MISIARCZYK \\ (Warszawa, UKSW)
}

\title{
PRYMAT KOSCIOLA/BISKUPA RZYMU W ŹRÓDłACH CHRZEŚCIJAŃSKICH II WIEKU
}

Refleksję nad tematyką prymatu Kościoła w Rzymie w źródłach chrześcijańskich II wieku warto rozpocząć od dwóch uwag natury ogólnej. Po pierwsze, porównując nawet pobieżnie fragmenty Nowego Testamentu, dotyczące pierwszeństwa Piotra wśród pozostałych Apostołów (Mt 16, 13-19; Łk 22, 31nn; J 21, 15-17; 1Kor 15,5$)$ z pozabiblijnymi tekstami chrześcijańskimi II wieku zauważamy, ze pierwsze zdecydowanie wyraźniej potwierdzają wyjątkowe miejsce Piotra w gronie Dwunastu niż pozostałe piszą o jego następcach. Albo jeszcze inaczej, teksty objawione, które dotyczą pierwszeństwa Piotra są jaśniejsze niż późniejsza refleksja nad nimi w tekstach wczesnochrześcijańskich II wieku. Oznaczałoby to, że nauka objawiona w tym względzie przewyższa zdecydowanie wczesnochrześcijańską refleksję nad prymatem Piotra w pierwotnym Kościele, co mogłoby wskazywać na jej rzeczywiste pochodzenie od samego Chrystusa, a nie wyraz samoświadomości Kościoła apostolskiego w Nowym Testamencie. W konsekwencji więc, i jest to druga uwaga, należy odróżnić wyraźnie pomiędzy pierwszeństwem Piotra w łonie Dwunastu (poziom Objawienia) ustanowionym przez samego Chrystusa, a pełną świadomością tego faktu w pierwotnym Kościele, która ulegała rozwojowi i kształtowała się w historii (poziom świadomości kościelnej). Często bowiem mylnie w badaniach historyczno-teologicznych nad rozwojem jakiejś idei zakłada się, że źródła późniejsze charakteryzują się wyższym poziomem świadomości niż wcześniejsze. I często tak bywa, ale nie zawsze jest to wzrastający postęp liniowy. Tego typu myślenie bywa szczególnie zwodnicze w przypadku badań porównawczych pomiędzy tekstami objawionymi i późniejszymi, nienatchnionymi. Pismo św. przekazuje nam bowiem „wyższy”, „obiektywny” poziom zamysłu Boga na temat prymatu Piotra, nie do końca zapewne uświadamiany sobie w calej rozciągłości przez bezpośrednich słuchaczy. Bóg objawił niektóre elementy swojej nauki niejako na wyrost, pozostawiając ich zgłębianie i werbalne określenie kolejnym pokoleniom chrześcijan. Fundamentalne rozróżnienie między wyraźną nauką objawioną na temat prymatu Piotra, a mniej wyraźną samoświadomością Kościoła poapostolskiego, pomoże nam, z jednej strony, nie 
pomniejszać całej wymowy przekazu nowotestamentalnego, ani też projektować na niego późniejszej samoświadomości Kościoła, z drugiej zaś nie dziwić się, iż ta samoświadomość jest mniejsza niż nauki objawionej.

Rekonstrukcja samoświadomości prymatu Kościoła lub biskupa Rzymu w chrześcijaństwie II wieku jest niezmiernie trudna, gdyż pojawia się ona jedynie w nielicznych tekstach tego okresu, i na dodatek często jako wątek okazjonalny. Poprawniej można by mówić o samoświadomości prymatu w poszczególnych wspólnotach chrześcijańskich niż w całym Kościele, gdyż źródła, jakie dotrwały do naszych czasów są zapisem takiej właśnie lokalnej refleksji. Środowiskiem jednak, co jest niezmiernie interesujące i ważne, łączącym wszystkie te świadectwa był Kościół lub biskup Rzymu. Są to: List do Koryntian Klemensa Rzymskiego, List do Rzymian Ignacego z Antiochii, kontrowersje dotyczące daty celebracji Paschy między biskupem Polikarpem ze Smyrny i papieżem Anicetem oraz biskupem Polikratesem z Efezu i papieżem Wiktorem, przekazane w Historii kościelnej Euzebiusza z Cezarei, wreszcie dzieła Tertuliana i Ireneusza $z$ Lyonu. Zanim przejdziemy do dokładnego studium wspomnianych źródeł, już ich pobieżna analiza pozwala sformułować pewne wstępne hipotezy badawcze. Po pierwsze, wyżej wymienione teksty pokazują wyraźnie że, jak zaznaczyłem wyżej, świadomość pierwszeństwa Kościoła Rzymu rozwijała się i kształtowała stopniowo w Kościele powszechnym. Po drugie, w najstarszych tekstach odnoszono ją do Kościoła lub biskupa w Rzymie. I po trzecie, w tekstach chrześcijańskich II wieku próżno byłoby doszukiwać się wyraźnej prezentacji prymatu Kościoła czy biskupa rzymskiego w kategoriach jurysdykcyjnych, charakteryzujących późniejsze wieki. Rozumiano go raczej jako posługę na rzecz jedności, choć w przyszłości ta posługa będzie ewoluować i obejmie również jurysdykcyjny prymat papieży. Byłoby jednak nieuprawnionym błędem metodologicznym narzucać tę później rozwiniętą w Kościele formę prymatu tekstom wcześniejszym. Ma rację Klaus Schatz stwierdzając, iż nie ma sensu stawiać pytania tekstom chrześcijańskim II wieku w stylu „Czy istniał wówczas prymat w naszym dzisiejszym rozumieniu”? Takie pytanie jedynie zaciemnia źródła i nie pozwala uchwycić rzeczywistej roli Kościoła i biskupa Rzymu u początku chrześcijaństwa ${ }^{1}$. Stawiaja je zaś najczęściej ci, którzy, chyba nie do końca świadomie, odmawiają Kościołowi prawa do późniejszej precyzacji formy prymatu biskupa i Kościoła w Rzymie. Teksty musimy bowiem interpretować w kontekście historycznym, literackim i teologicznym danej epoki.

W najnowszych badaniach historycznych i teologicznych nad prymatem biskupa i Kościoła w Rzymie, słusznie oddziela się od siebie dwa aspekty tej

${ }^{1}$ Por. K. Schatz, Der päpstliche Primat. Seine Geschichte von den Ursprïngen bis zur Gegenwart, Würzburg 1990, tłum. J. Zakrzewski: Prymat papieski od poczqıłów do wspólczesności, Kraków 2004, 16. 
tematyki: odnoszenie prymatu do Rzymu i samoświadomość prymacjalna Kościoła/biskupa rzymskiego ${ }^{2}$. Takie rozróżnienie pozwala nam bowiem odpowiedzieć na dwa zasadnicze pytania: jak z jednej strony Kościół lub biskup Rzymu był postrzegany $w$ pierwotnym chrześcijaństwie, $z$ drugiej natomiast, jak sam Kościół lub biskup rzymski rozumiał swoją posługę. Obecna analiza podąży również tą drogą. Ponieważ List do Koryntian Klemensa Rzymskiego i Ireneusz z Lyonu będą zaprezentowani w innych opracowaniach, tutaj skoncentruję się na pozostałych tekstach chrześcijańskich II wieku dotyczących naszej tematyki: List do Rzymian Ignacego Antiocheńskiego, świadectwo Hegezypa, niektóre fragmenty dzieł Tertuliana oraz źródła związane $\mathrm{z}$ kontrowersją dotyczącą daty celebracji Paschy w II wieku.

\section{PRYMAT ODNOSZONY DO KOŚCIOŁA/BISKUPA W RZYMIE}

1. „Przewodzenie miłości” w Liście do Rzymian Ignacego Antiocheńskiego. Najstarszym tekstem chrześcijańskim II wieku, który nawiązuje do tematyki pierwszeństwa Kościoła w Rzymie, jest List do Rzymian Ignacego, biskupa Antiochii. Jak wiemy, po jego aresztowaniu odbył się na miejscu jakiś proces rozpoznawczy zgodnie $\mathrm{z}$ formulą cognitio extra ordinem, zakończony wyrokiem skazującym. Podczas podróży do Rzymu napisał on siedem listów do różnych wspólnot chrześcijańskich w Azji Mniejszej, w tym jeden list do Polikarpa, biskupa Smyrny i jeden - najbardziej interesujący nas tutaj, właśnie do Rzymian $^{3}$. Euzebiusz z Cezarei datuje śmierć Ignacego na 107 r., współcześni badacze przesuwają ją na lata $110-117^{4}$, ale i tak, bez względu na przyjęcie jakiejkolwiek daty, List do Rzymian pozostaje najstarszym źródłem chrześcijańskim II wieku traktującym o naszej tematyce. Od dawna już zainteresowanie badaczy starożytności chrześcijańskiej budził początek Listu do Kościoła w Rzymie:

„Ignacy, zwany również Teoforem, do Kościoła obdarzonego miłosierdziem przez hojność Najwyższego Ojca i Jego Jedynego Syna, Jezusa Chrystusa, Kościoła wielce umiłowanego i oświeconego $\mathrm{z}$ woli Tego, z którego woli istnieje wszystko, co istnieje, w miłości Jezusa Chrystusa, Boga naszego, Kościoła, który przewodzi w krainie Rzymian, godny Boga, godny czci, godny błogosławieństw, godny

${ }^{2}$ Por. bardzo dobrą syntezę ks. H. Seweryniaka, Swiadectwo $i$ sens. Teologia fundamentalna, Plock 2001, 454-458.

${ }^{3}$ Ogólne wprowadzenie do Listów Ignacego - zob. M. Starowieyski, Wołanie o jedność - św. Ignacy Antiocheński, w: Pierwsi świadkowie, BOK 10, Kraków 1998, 104-112; Th. Camelot, Introduction, SCh 10bis, Paris 1998, 9-54; R.E. Brown - J.P. Meier, Antioche et Rome, Paris 1988, 101-113.

${ }^{4}$ Por. N. Brox, Zeuge und Märtyrer, München 1961, 203; P. Nautin, Ignazio di Antiochia, DPAC II 1743-1745; H. Pietras, Poczq̨iki teologii Kościola, Kraków 2000, 24. 
pochwały, godny powodzenia, godny czystości [wiary] i przewodzący w miłości, naznaczony prawem Chrystusa i imieniem Ojca. [Braciom] w ciele $\mathrm{i}$ w duchu zjednoczonym we wszystkich Jego przykazaniach, trwającym niewzruszenie w lasce Bożej, obmytym z wszelkiej obcej barwy, serdeczne pozdrowienie w Jezusie Chrystusie, Bogu naszym i nieskazitelnosci"s.

Warto zaraz na początku zauważyć, że słowa te napisał biskup Antiochii, prawdopodobnie następca św. Piotra i jednego z najważniejszych Kościołów tamtej epoki. Dalej, wstęp ten należy do najdłuższych wśród listów Ignacego i zawiera bardzo oryginalne elementy jego nauczania. Najwięcej kontrowersji wśród uczonych wzbudził słynny zwrot, którym Ignacy określa Kościół w Rzy-

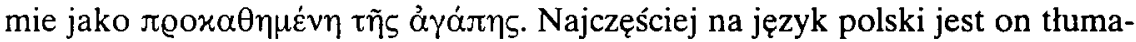
czony przez określenie „przewodzący w miłości”, ale warto pamiętać, że $\tau \tilde{\eta} \zeta$

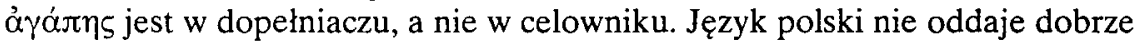
różnicy w grece pomiędzy tymi przypadkami, lecz sens wyrażenia byłby „przewodzenie miłości". Interpretacja tego wyrażenia w przeszłości była bardzo mocno uwarunkowana wstępnymi założeniami konfesyjnymi. Badacze katoliccy rozumiejąc termin „miłośc” jako synonim communio kościelnej, dostrzegali w nim świadectwo potwierdzające, że Rzym zajmował pozycję jurysdykcyjnego „przewodzenia więzom miłości” w Kościele powszechnym. Schatz słusznie podkreśla, że w II wieku owego pierwszeństwa Kościoła w Rzymie raczej nie pojmowano jeszcze w kategoriach jurysdykcyjnej zależności innych Kościołow od Kościoła w Rzymie ${ }^{6}$. Natomiast uczeni protestanccy takie rozumienie tekstu podważali. Th. Zahn, A. Harnack i W. Bauer byli zdania, że określenie to wyraża wdzięczność za troskliwą opiekę Kościoła w Rzymie nad innymi, uboższymi wspólnotami chrześcijańskimi ${ }^{7}$. Wyrażenie odnosiłoby się więc do dobroczynności i pomocy charytatywnej, świadczonej przez Kościół w Rzymie na rzecz innych. Krótko mówiąc, fragment byłby pochwałą działalności Kościoła rzymskiego, którą dzisiejszym językiem określilibyśmy mianem caritas. Prawdą jest, że Kościół rzymski rzeczywiście słynął w II wieku z tego, iż hojnie wspieral

${ }^{5}$ Ad Romanos. Pozdrowienie, tłum. A. Swiderkówna, BOK 10, 128, SCh 10bis, 106-107:

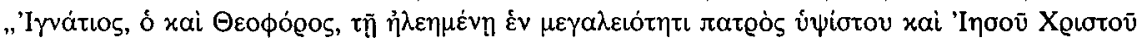

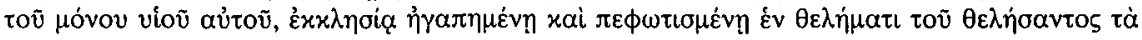

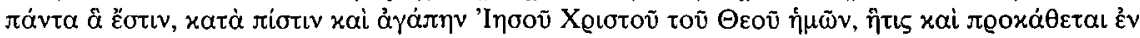

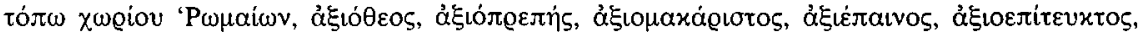

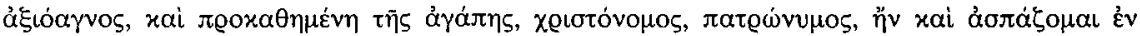

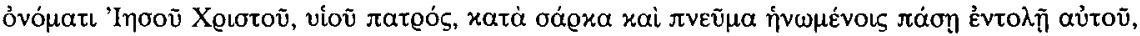

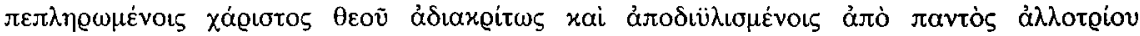

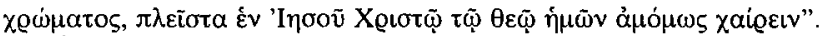

${ }^{6}$ Por. Schatz, Prymat papieski, s. 19.

7 Zob. Th. Zahn, Ignatius von Antiochien, Gotha 1873, 23nn; tenże, Ignatii et Polycarpi Epistulae, martyria, fragmenta. Patrum Apostolicorum opera, fasc. 2, Lipsiae 1876; A. Harnack, Die Zeit des Ignatius und die Chronologie der antiochenischen Bischöfe bis Tyrannus, Leipzig 1978, 45n; W. Bauer, Die Briefe des Ignatius von Antiochien und der Polycarpbrief, Tübingen 1920, 67nn. 
inne wspólnoty chrześcijańskie cierpiące niedostatek. Potwierdza to również biskup Dionizy z Koryntu w swoim Liście do Rzymian skierowanym na ręce ówczesnego papieża Sotera:

„Od początku bowiem jest u Was w zwyczaju, by braciom świadczyć przeróżne dobrodziejstwa, by do wielu Kościołów rozrzuconych po wszystkich miastach posyłać zapomogi, i w ten sposób zaspokajać potrzeby biednych oraz pomagać braciom w kopalniach cierpiącym"8.

Dionizy chwali pomoc świadczoną przez chrześcijan rzymskich braciom cierpiącym niedostatek środków do życia lub skazanym do ciężkiej pracy w kopalniach. Takie jednak rozumienie naszego fragmentu tekstu jest problematyczne $\mathrm{z}$ dwóch powodów. Pierwszy argument ma charakter ściśle filologiczny: otóż czasownik $\pi \varrho \circ x \alpha ́ \theta \eta \mu \alpha$ nigdy nie przyjmował w grece klasycznej ani chrześcijańskiej znaczenia „świadczyć pomoc lub dobroczynność”, lecz najczęściej „zasiąść przed, (z gen.) chronić, bronić, przewodzić"9. Gdyby w naszym tekście

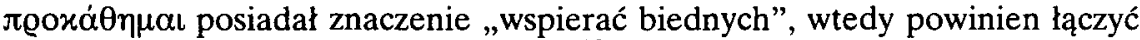
się z celownikiem, a nie $\mathrm{z}$ dopełniaczem ${ }^{10}$; po drugie, znaczenie interesującego nas czasownika należy określić w kontekście wszystkich listów Ignacego, który przecież z łatwością mógł nadać mu nowe znaczenie. Warto więc pamiętać, że

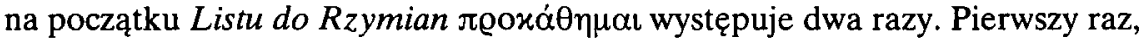
gdy Ignacy określa wspólnotę chrześcijan rzymskich jako Kościół, „który prze-

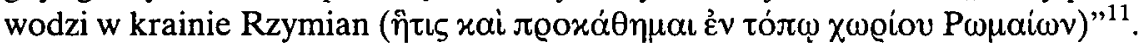
Podobnie jak poprzednie, również i to wyrażenie sprawiło niemało kłopotów badaczom Listów Ignacego. Niektórzy proponowali odrzucenie tej wersji, ale jest ona dobrze potwierdzona przez tradycję manuskryptyczną. Propozycja

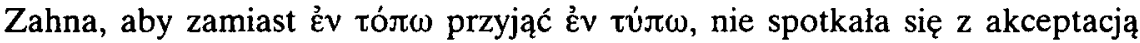

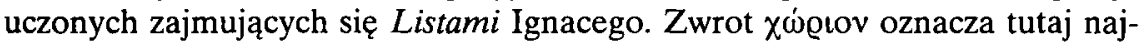
prawdopodobniej miasto Rzym wraz z dzielnicami podmiejskimi (Roma suburbicaria). Nie bez znaczenia pozostaje również '̉v, który precyzuje w naszym zwrocie, iż chodzi o przewodniczenie „w" krainie, a nie zarządzanie krainą. Cały więc zwrot oznaczałby, że Kościół rzymski, w całym rejonie (krainie) Rzymian, w którym został ustanowiony, przewodzi. Kościół rzymski przewodzi więc innym Kościołom zgrupowanym w rejonie Rzymu (miasto i przedmieścia $)^{12}$. Nie trzeba dodawać, że tekst nie mówi nic o pierwszeństwie biskupa Rzymu nad biskupami podmiejskimi (episcopi suburbicarii). Użycie zaś przez

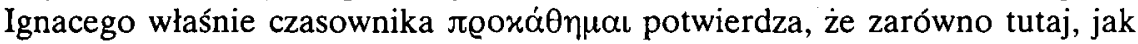
i w poprzednio analizowanym fragmencie, chodzi o rzeczywiste przewodnic-

\footnotetext{
${ }^{8}$ Eusebius, HE IV 23, thum. A. Lisiecki, POK 3, 182-183.

9 Por. H.G. Liddel - R. Scott, A Greek-English Lexicon, Oxford 1994 ${ }^{10}, 1483$.

${ }^{10}$ Por. SCh 10bis, 107, przypis 3.

11 Ad Romanos. Pozdrowienie, SCh 10bis, 106, BOK 10, 128.

12 Por. Camelot, SCh 10bis, 106, przypis 1.
} 
two, a nie tylko o przewyższanie innych Kościołów swoim miłosierdziem czy szczodrobliwością. We wszystkich Listach Ignacego ten czasownik występuje tylko 4 razy - 2 razy właśnie w Liście do Rzymian i 2 razy w Liście do Magnezjan $^{13}$. W Liście od Magnezjan termin ten wskazuje wyraźnie na przewodzenie biskupa lub przewodniczącego wspólnoty:

„[...] zaklinam was, starajcie się wszystko czynić w zgodzie Bożej pod kierunkiem

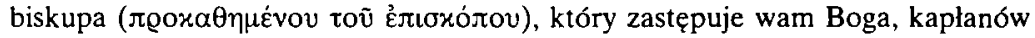
zastępujących radę Apostołów i moich najdroższych diakonów, mających udzial w posłudze Jezusa Chrystusa [...]. Niech nie będzie w was niczego, co mogłoby was dzielić, lecz jednoczcie się z biskupem i tymi, co wam przewodzą (roĩs $\pi \varrho 0 \varkappa \alpha \theta \eta \mu \dot{v}$ oเ 5$) " 14$.

Widzimy wyraźnie, że w tych fragmentach chodzi o biskupów, prezbiterów i diakonów przewodzących wspólnotom chrześcijańskim. W określeniu więc „przewodzi w krainie Rzymian”, jak też „przewodzący miłości”, chodzi o rzeczywiste przewodzenie, czyli swego rodzaju pierwszeństwo. Jak rozumieć jednak do końca te zwroty? Czy łączą się one ze sobą znaczeniowo i wzajemnie wyjaśniają, czy też nie? Pierwsze znaczenie, jakie narzuca się już przy powierzchownej lekturze tych określeń, mogłoby odnosić ich znaczenie jedynie do Rzymu i okolic. Kościół w Rzymie przewodzi innym, okolicznym Kościołom podmiejskim, a drugi zwrot „przewodzi miłości” precyzowałby tylko, że jest to przewodzenie charakteryzujące się postawą miłości braterskiej. Pisałem wyżej, że chodzi o rzeczywiste przewodzenie Kościoła w Rzymie, a nie jedynie o swego rodzaju większą szzczodrobliwość czy troskę tego Kościola o inne wspólnoty. By dokładniej zrozumieć sens interesujących nas wyrażeń, trzeba starać się precyzyjniej określić, co jest przedmiotem tego przewodzenia, tzn. jak rozumieć termin $\dot{\alpha} \gamma \alpha \dot{\pi} \eta \eta$.

F.X. Funk analizując występowanie tego terminu w listach Ignacego doszedł do wniosku, że używa on go jako synonimu Kościoła lokalnego, wspólnoty chrześcijańskiej ${ }^{15}$. Cały zwrot rozumie on więc jako przewodzenie spo-

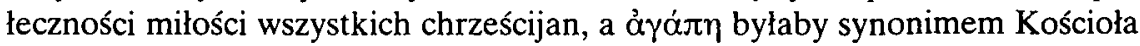
powszechnego. Nawet jeśli przewodzenie nie byłoby rozumiane w sensie jurysdykcyjnym, to dotyczyłoby przewodzenia Kościoła w Rzymie całemu Kościolowi powszechnemu. Argument ten stanowi pewną propozycję rozwiązania tej kwestii, lecz jego baza filologiczna jest stosunkowo słaba ${ }^{16}$. Wystarczy przyj-

${ }^{13}$ Por. E.J. Goodspeed, Index Patristicus sive Clavis Patrum Apostolicorum Operum, Leipzig $1907,205$.

${ }_{14}$ Ad Magnesios 6, 1-2, SCh 10bis, 84, BOK 10, 121.

15 Por. F.X. Funk, Der Primat der römischen Kirche nach Ignatius und Irenaeus: Kirchengeschichtliche Abhandlungen und Untersuchungen, I, Paderborn 1897 (Ad Philadelphenses 11, 2; Ad Smyrnaeos 12, 1: Ad Trallianos 13, 1; Ad Romanos 9, 3); tenże, Patres Apostolici, Tübingen 1913².

16 Por. Camelot, SCh 10bis, 107, przypis 3. 
rzeć się dokładniej tekstom zaproponowanym przez Funka. W Liście do Trallan czytamy: „Pozdrawia was milość ( $\dot{\eta} \dot{\alpha} \gamma \alpha \dot{\alpha} \eta)$ braci ze Smyrny i Efezu”, ${ }^{17}$ w Liście do Smyrneńczyków: „Pozdrawia was miłość ( $\eta \dot{\alpha} \gamma \alpha \dot{\pi} \eta$ ) braci z Troady, skąd piszę do was przez Burrosa”, ${ }^{18}$ w Liście do Rzymian: „Pozdrawia was mój duch i miłość Kościołów, które przyjęły mnie w imię Jezusa Chrystusa, nie jak zwykłego przechodnia"19. Natomiast List do Filadelfian $(11,2)$ zawiera to samo pozdrowienie, co List do Smyrneńczyków. Trudno byłoby dopatrzyć się w tych określeniach synonimu Kościoła lokalnego lub Kościoła powszechnego. $Z$ in-

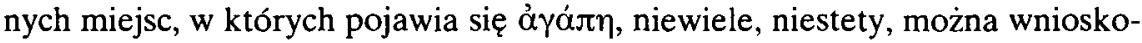
wać, gdyż termin ten występuje w znaczeniu chrześcijańskiej miłości braterskiej lub miłości do Jezusa Chrystusa ${ }^{20}$. J. Thiele wykazał zresztą już wcześniej, że propozycja Funka nie wpisuje się dobrze w całość myśli teologicznej Ignacego $^{21}$. Warto również dodać, iż antyczne tłumaczenia łacińskie, syryjskie i armeńskie jego listów nie potwierdzają takiego rozumienia interesującego nas $z_{w r o t u}{ }^{22}$. Thiele zaproponował więc, by $\alpha \hat{\gamma} \alpha \dot{\pi} \eta$ w naszym tekście rozumieć jako całość życia nadprzyrodzonego, jakie Chrystus zapalił w ludziach swoją miłością. Jego zdaniem, Ignacy w określeniu „przewodzący miłości” uznawałby w Kościele rzymskim autorytet przewodzenia w tym, co stanowi istotę chrześcijaństwa i nowy porządek, który wprowadziła w świat miłość Chrystusa do ludzi. Wniosek ten powtarzany jest przez większość późniejszych badaczy oraz w opracowaniach podręcznikowych aż po nasze czasy. Ignacy miałby więc na myśli pierwszeństwo Kościoła w Rzymie w tym, co stanowi istotę chrześcijaństwa, czyli w wierze i miłości ${ }^{23}$. Określenia ,wiara i miłość" mają jednak bardzo szerokie znaczenie i nie bardzo wiadomo, co dokładnie można by pod nimi rozumieć w II wieku w kontekście pierwszeństwa Kościoła w Rzymie. Chyba, że wiarę odniesiemy do jej przedmiotu, czyli tajemnicę odkupienia, a miłość pojmiemy jako fundament dla nowych obyczajów chrześcijańskich, to wtedy sens wyrażenia byłby taki, że Kościół w Rzymie przewodzi temu, co istotne w chrześcijaństwie, czyli w sprawach wiary i obyczajów. Nie można wykluczyć takiego rozumienia zwrotu przez Ignacego, lecz brakuje nam, niestety, dodatkowych elementów, by taki sens ostatecznie wykluczyć lub potwierdzić. Prze-

${ }^{17}$ Ad Trallianos 13, 1, SCh 10bis, 105, BOK 10, 127.

${ }^{18}$ Ad Smyrnaeos 12, 1, SCh 10bis, 142, BOK 10, 139.

19 Ad Romanos 9, 3, SCh lobis, 118, BOK 10, 131.

20 Por. Ad Ephesios 1, 1; 2, 1; 3, 2; 9, 1; 14, 1-2; Ad Magnesios 1, 1; 5, 2; 7, 1; 13, 1; 14, 1; Ad Trallianos 3, 2; 6, 1;8, 1;12,3; Ad Romanos 2,3;7,3;9, 1 ;d Philadelphenses 1,$1 ; 3,3 ; 6,2 ; 6,2 ; 9,2$; Ad Smyrnaeos 1, 1; 6, 1-2; 8, 2; 13, 2; zob. Goodspeed, Index Patristicus, s. 2.

21 Por. J. Thiele, „Vorrang in der Liebe”, ,Theologie und Glaube” 9 (1927) 701-709.

22 Por. J. Quasten, Patrologia, I, Casale Monferrato 1993, 69.

23 Por. A. Erhard, Die Kirche der Märtyrer, Berlin 1932, 275-276; O. Perler, Ignatius von Antiochien und die römische Christengemeinde, „Divus Thomas” 22 (1944) 413-451; G. Bardy, La théologe de l'Église de saint Clément de Rome à saint Irénée, Paris 1954, 113-117; Camelot, SCh 10bis, 107, przypis 3. 
wodnictwo to byłoby oczywiście w II wieku pierwszeństwem w sensie religijnym i duchowym, nie zaś jurysdykcyjnym ${ }^{24}$. Wówczas w Liście do Rzymian Ignacego mielibyśmy rzeczywiście początek późniejszego prymatu Kościoła w Rzymie (jeszcze nie biskupa) w sprawach wiary i obyczajów. Są to jednak tylko przypuszczenia niezmiernie trudne do ostatecznej weryfikacji i naznaczone niebezpieczeństwem projektowania na tekst późniejszej formy prymatu biskupa Rzymu. Nie do końca przekonuje i wątpliwe metodologicznie jest twierdzenie, że późniejszy kierunek rozwoju nauki o prymacie jurysdykcyjnym biskupa Rzymu dowodzi obecności tej nauki już w stanie embrionalnym lub potencjalnym w Liście do Rzymian Ignacego. Interesuje nas tutaj odpowiedź na pytanie o stan samoświadomości Kościoła II wieku w kwestii pierwszeństwa Kościoła lub biskupa Rzymu i warto pamiętać, iż ta samoświadomość rozwijała się i pogłębiała warunkowana nowymi kontekstami historycznymi. Oczywistą jest rzeczą, że późniejsze jurysdykcyjne rozumienie prymatu biskupa Rzymu, nie wzięło się z niczego, ani nie zostało całkowicie wymyślone i musiało się opierać na wcześniejszych przekazach, ale to nie wyklucza rozwoju rozumienia roli biskupa Rzymu w Kościele. W II wieku mógł to być tylko rodzaj przywództwa duchowego, natomiast w wiekach późniejszych prymat jurysdykcji. Ważniejszym więc byłoby tutaj pytanie, czy Kościół, albo sam biskup Rzymu, mogą w zależności od kontekstu historycznego zmieniać formę posługi następców św. Piotra. Chrystus polecil Piotrowi i jego następcom misję „umacniania braci w wierze", lecz określenie konkretnej jej formy pozostawił ludziom. W jednej epoce wystarczy przewodnictwo duchowe, a w innej okazuje się potrzebny prymat jurysdykcji. Propozycja Jana Pawła II, by wspólnie z innymi Kościołami chrześcijańskimi przedyskutować sposób posługi papieskiej w naszych czasach, potwierdza, że możliwa jest ewolucja, a może nawet i samoograniczenie roli biskupa Rzymu w Kościele.

Podczas gdy trudno określić dokładne znaczenie zwrotu „przewodzący miłości”, to nie ulega wątpliwości, że Kościół w Rzymie darzy Ignacy wyjątkowym szacunkiem. Cały List do Rzymian potwierdza, że autor przyznaje mu pozycję wyjątkowo honorową. To Kościół, który „przewodzi w krainie Rzymian" i „pouczal innych" (Rom. 3, 1). Ignacy we wszystkich swoich listach zachęca poszczególne wspólnoty do jedności, poucza je i udziela im różnych rad, z wyjątkiem właśnie Kościoła w Rzymie. I nie jest to tylko zwykłe niedopatrzenie. Biskup Antiochii czuje się niegodny pouczać Kościół, którego autorytet pochodzi od apostołów:

„Nie wydaję wam rozkazów, jak Piotr i Paweł. Oni - Apostołowie, ja - skazaniec, oni - wolni, ja - do dziś dnia niewolnik"25.

24 Por. Schatz, Prymat papieski, s. 20.

${ }^{25}$ Ad Romanos 4, 3, SCh 10bis, 113, BOK 10, 129. 
Oprócz bardzo ważnego świadectwa pobytu Piotra i Pawla w Rzymie, na podkreślenie zasługuje fakt określenia przez Ignacego fundamentu autorytetu Kościoła w Rzymie. Jest nim nauczanie apostołów Piotra i Pawła. Dlatego właśnie określa go jako Kościół „godny czystości wiary i przewodzący w miłości" (por. tamże, wstęp).

$\mathrm{Na} z a k o n ́ c z e n i e ~ t y c h$ refleksji chciałbym zaproponować jeszcze inną interpretację wyrażenia „przewodzący miłości”, odnosząc jego sens do 21 rozdziału Ewangelii św. Jana. Jak wiemy, współczesna egzegeza historycznoliteracka przypuszcza, że rozdział ten został dodany później do całości IV Ewangelii przez Jana lub któregoś z jego uczniów. W J 21, 15-17 mamy słynny opis przekazania władzy pasterskiej Piotrowi w formie pytania i zapowiedź jego męczeńskiej śmierci $(21,18-19)$. Jezus pyta Piotra o większą miłość „Szymonie, synu Jana, czy miłujesz mnie więcej aniżeli ci?" Posługa Piotra ma być oparta na większej, pełnej i całkowitej miłości do Pana, co potwierdzają potrójne pytania. Ma on żywić trzodę Chrystusową oraz strzec jej przed rozbiciem i fałszywymi naukami. W „owcach" i „barankach” można by się dopatrywać całego Kościoła ${ }^{26}$. Piotr wypełnił kryterium większej miłości oddając swoje życie za Chrystusa na wzgórzu watykańskim, dlatego też Kościół w Rzymie, zbudowany na jego osobie i męczeńskiej śmierci, nadal jest powołany do większej milości do Pana. Kościół w Rzymie na wzór swego pasterza, Piotra, jest wezwany do „przewodzenia miłości”, tzn. do większej i doskonalszej miłości Pana, niż inne Kościoły. W przekonaniu Kościoła pierwotnego, zachęta do większej miłości została przez samego Chrystusa połączona $z$ nakazem troski dostarczania duchowego pokarmu całemu Kościołowi oraz obroną Go przed

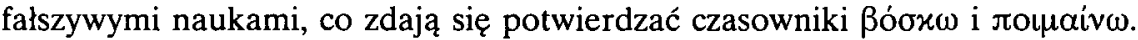
Misja Piotra, by paść i strzec cały Kościół, na początku II wieku nie była jeszcze rozumiana na zasadzie prymatu jurysdykcyjnego nad innymi wspólnotami, ale raczej jako przywództwo duchowe i religijne. Nie jest więc wykluczone, że Ignacy przekazał nam tutaj tę samą tradycję wschodnią (Antiochia), pochodzącą być może z tego samego okresu, co przekaz Janowy (Efez) o powołaniu Piotra i jego następców do większej miłości oraz zleceniu mu troski o cały Kościół.

Wnioski, do jakich można dojść po analizie początku Listu do Rzymian w kwestii przewodzenia Kościoła w Rzymie, mają różny stopień pewności. Ignacy nie odnosi przewodzenia do biskupa Rzymu, ale do Kościoła w Rzymie. W II wieku było to $z$ pewnością przewodzenie duchowe i religijne Kościoła w Rzymie całemu Kościołowi powszechnemu. Niewykluczone, że dotyczyło spraw wiary i obyczajów, i wtedy nasz tekst byłby rzeczywiście świadectwem prymatu Kościoła w Rzymie (jeszcze nie biskupa) właśnie w sprawach wiary i obyczajów. Brakuje jednak elementów, które pozwoliłyby takie rozumienie

${ }^{26}$ Por. Seweryniak, Świadectwo $i$ sens, s. 447. 
przewodzenia ostatecznie potwierdzić lub wykluczyć. Jest natomiast mało prawdopodobne, by Ignacy odnosił określenie Kościoła w Rzymie, jako „przewodzącego miłości” w sensie prymatu jurysdykcyjnego na całym Kościołem. Być może dlatego, że prymat jurysdykcyjny nie był w tamtym czasie potrzebny, a dopiero w przyszłości, gdy będzie tego wymagał inny kontekst historyczny, misja duchowej troski wraz z obroną przed fałszywymi naukami mogła przerodzić się również w prymat jurysdykcyjny Kościoła w Rzymie. Dane Objawienia są dosyć wyraźne, co do tego, że Chrystus powierzył Piotrowi misję duchowego przewodzenia całemu Kościołowi, natomiast wydaje się, iz określenie konkretnej formy sprawowania tej posługi w różnych kontekstach historycznych, pozostawił jego następcom i Kościolowi.

2. Świadectwo Hegezypa. W badaniach nad prymatem biskupa lub Kościoła w Rzymie często przytacza się też świadectwo judeochrześcijanina Hegezypa, który przybył do Rzymu, by ustalić listę kolejnych biskupów tworzących w nim sukcesję apostolską ${ }^{27}$. Nie dotrwały, niestety, do naszych czasów jego Pamiętniki, napisane w 5 księgach i poświęcone najprawdopodobniej polemice z fałszywą gnozą. Fragmenty tego dzieła przekazuje nam Euzebiusz z Cezarei w swojej Historii kościelnej ${ }^{28}$. Autor żył na Wschodzie w latach ok. 110 do ok. 185 roku. Euzebiusz, który czytał zapewne jego dzieło, twierdzi, że przytaczał w nim szczegóły z Ewangelii wedtug Hebrajczyków, niektóre właściwości języka syryjskiego i hebrajskiego oraz ustnej tradycji żydowskiej, skąd historyk Kościoła wnioskuje, że był chrześcijaninem pochodzenia żydowskiego ${ }^{29}$. Kontekst wypowiedzi Hegzypa dotyczył, według Euzebiusza, mnożących się przeróżnych heretyckich sekt w Kościele pierwotnym. Oto sam tekst:

„Ten sam pisarz opowiada również o początkach herezji swych czasów w takich oto słowach: «A po męczeństwie Jakuba Sprawiedliwego, takim jak Pan, za tę samą sprawę, został ustanowiony biskupem Symeon, syn Kleopasa, stryja Chrystusa, któremu wszyscy dali pierwszeństwo, gdyż i on był krewnym Pańskim. Dlatego zaś Kościól zwano dziewicą, bo jeszcze nie był splamiony falszywą nauką. Początek zaś błędnym naukom dal Tebutis, który, gdy nie zostal biskupem, zacząl szerzyć zepsucie płynące $z$ siedmiu sekt, rozpowszechnionych wśród ludu, do których również sam należał. Z nich wywodzi się Szymon, a od niego symonici, Kleobios, a z niego kleobianie, Dositeos, a z niego dositianie, Gortaios, a $\mathrm{z}$ niego goracjanie i masboteianie. Dalej meandrianie, marcjonici, karpokratianie, walentynianie, bazylidianie i saturnianie. A każdy z nich swoją własną, różniąca się od innych, naukę wprowadził. $\mathrm{Z}$ nich idą fałszywi mesjasze, prorocy $\mathrm{i}$ apostołowie, którzy rozdarli jedność Kościoła ową zgubną nauką o Bogu i Jego Chrystusie»"30.

\footnotetext{
27 Por. F. Scorza Barcellona, Egesippo, DPAC I 1108-1109.

${ }^{28}$ Por. Schatz, Prymat papieski, s. 27; Seweryniak, Swiadectwo i sens, s. 455.

${ }^{29}$ Por. Eusebius, HE IV 22, 8.

30 Tamże IV 22, 4-6, SCh 31, 200-201, POK 3, 179-180 (ze zmianami).
} 
Kościół antyczny zareagował w dwojaki sposób na zagrożenie różnego rodzaju nauk błędnowierczych, rozpowszechnianych właśnie w II wieku, a zwłaszcza gnozę: podejmując systematyczną polemikę na poziomie „naukowym”, którą rozwijało zwłaszcza środowisko aleksandryjskie, najlepiej do tego przygotowane teologicznie (Klemens Aleksandryjski, Orygenes), albo przeciwstawiając prywatnemu oświeceniu gnostyków publiczną Tradycję Apostolską (Ireneusz z Lyonu). Nas interesuje tutaj zwłaszcza drugi sposób polemiki z gnostykami, tzn. odwołanie się do publicznej tradycji apostolskiej. Autorzy chrześcijańscy II wieku wychodzili $z$ założenia, że prawdziwa wiara przetrwała w Kościołach założonych przez apostołów dzięki nieprzerwanej sukcesji apostolskiej. Ireneusz z Lyonu jest jednym $\mathrm{z}$ najważniejszych świadków takiego sposobu walki $\mathrm{z}$ gnostykami. W jego Adversus haereses czytamy:

„Otóż każdy, kto chce poznać prawdę, może stwierdzić w każdym Kościele tradycję apostolów na całym świecie. I możemy wyliczyć tych, których apostołowie ustanowili biskupami oraz ich następców aż do nas. Niczego ani nie słyszeli ani nie uczyli, co (gnostycy) majacząc podają. Albowiem, gdyby apostołowie znali «sekretne tajemnice», których nauczali «doskonałych» tylko na osobności i w ukryciu przed innymi, to by je przede wszystkim winni przekazać tym, których pieczy powierzyli same Kościoły. Chcieli bowiem, żeby ci, których zostawili jako swoich następców i którym przekazali swój urząd nauczycielski, byli «doskonałymi» i nienagannymi [...]. Gdy błogosławieni apostołowie założyli i zbudowali Kościół, przekazali urząd biskupowi Linusowi [...]. Następcą jego był Anaklet. Po nim na trzecim miejscu po apostołach został biskupem Klemens [...]. Następcą Klemensa był Ewaryst, a Ewarysta Aleksander, a potem szósty po apostołach nastał Ksystus (Sykstus), po nim zaś Telesfor. Potem był Hygin, następnie Pius, a po nim Anicet, następcą Aniceta był Soter, a teraz na dwunastym miejscu po apostołach, dzierży urząd biskupi Eleuteros. Tym porządkiem i takim następstwem tradycja apostolska w Kościele i gloszenie prawdy dotarło do naszych czasów. Taki oto jest najpełniejszy dowód, że jest jedna i ta sama wiara ożywiajaca, zachowana w Kościele od apostołów aż do dziś i przekazywana w prawdzie"31.

Ten fragment pokazuje nam wyraźnie, że tradycja apostolska, przechowana w Kościołach założonych przez apostołów jest gwarantem prawdziwości nauki chrześcijańskiej przeciw swoistej prywatyzacji wiary wśród gnostyków. Przytoczyłem świadectwo Ireneusza, gdyż jest ono bardziej wyraźne niż Hegezypa, ale sądzę, że w taki właśnie klimat polemiki antygnostyckiej trzeba wpisać świadectwo tego ostatniego, by je właściwie zrozumieć.

Hegezyp w drodze do Rzymu spotyka się z różnymi biskupami ówczesnego świata chrześcijańskiego, choć wprost wzmiankuje tylko Korynt i Rzym, gdzie stara się odtworzyć listę sukcesji biskupów od apostołów do jego czasów i wszędzie znajduje tę samą naukę chrześcijańską. Oto przekaz Euzebiusza:

${ }^{31}$ Adversus haereses III 3, 1-3 passim, SCh 211, 30-38. 
„Otóż Hegezyp zostawił nam w pięciu księgach swych Wspomnień najwspanialszy pomnik swojej wiary. Opowiada w nich, że podczas swej podróży do Rzymu zetknął się z bardzo wielu biskupami, i że u wszystkich znalazł tą samą naukę. Po kilku slowach poświęconych Listowi Klemensa do Koryntian powiada, co następuje, a czego warto posłuchać. «I trwał Kościół Koryntian w prawowierności aż do Prymusa, który w Koryncie sprawował urząd biskupi. Zetknąłem się z nim, gdy jechałem do Rzymu i przestawałem z Koryntianami przez kilka dni ciesząc się razem z nimi czystością ich wiary. Gdy byłem w Rzymie ustaliłem sukcesję aż do Aniceta, którego diakonem był Eleuteros. A po Anicecie następstwo objął Soter, po nim zaś Eleuteros. W każdej zaś sukcesji i w każdym mieście tak się rzeczy mają, jak to nakazuje Prawo, Prorocy i Pan»"32.

Kilka elementów w tym tekście zasługuje na podkreślenie. Otóż, Hegezyp odwiedzając różne wspólnoty chrześcijańskie wraz z ich pasterzami, wszędzie znajduje jedną i tę samą naukę chrześcijańską. Szczegółowo wspomina tylko o Kościele w Koryncie i Rzymie. Kościół koryncki chwali za czystość wiary i wierność nauczaniu apostołów. Sporządza również listę sukcesji biskupów Kościoła korynckiego aż do Prymusa, a Kościoła rzymskiego do Aniceta. Nie wspomina jednak imiennie poprzedników ówczesnego biskupa Koryntu ani też Aniceta, wzmiankuje natomiast jego następców w Kościele rzymskim, tzn. Sotera i Eleuterosa. Nie wiemy, dlaczego wspomina tylko o Kościele w Koryncie i Rzymie, a nie mówi nic np. o Kościele w Efezie czy innych założonych przez apostołów. Podsumowuje jedynie, że w każdej sukcesji i w każdym mieście przekazywana jest prawowierna nauka chrześcijańska. Stwierdza przeciw gnostykom, iż w ten sposób zachowana została ciągłość tradycji apostolskiej do jego czasów. Czy mamy jednak w tym tekście wyraźne odniesienie prymatu do Kościoła w Rzymie? Schatz słusznie podkreśla, że, choć Hegezyp pochodził ze Wschodu, to interesuje się szczególnie listą sukcesyjną biskupów rzymskich, którą sprawdza na miejscu. Chociaż nadal trwają dyskusje pomiędzy badaczami, czy Hegezyp dotarł do Rzymu, by zweryfikować autentyczność tradycji apostolskiej w nim przechowywanej czy też jedynie, by spisać listę biskupów rzymskich $^{33}$, to jednak antygnostycki charakter jego wypowiedzi wskazuje wyraźnie, iż nie chodziło mu jedynie o listę sukcesyjną biskupów, ale również o tradycję apostolską przechowaną w Kościele rzymskim. Obydwa te elementy zresztą ściśle się ze sobą lączą: lista sukcesyjna jest gwarantem przechowania publicznej tradycji apostolskiej, a ta z kolei argumentem przeciwko ,sekretnym objawieniom" gnostyków. Sama lista sukcesyjna biskupów rzymskich, bez weryfikacji przechowania w tamtejszym Kościele prawowiernej nauki apostolskiej, nie byłaby żadnym argumentem w polemice $\mathrm{z}$ gnostykami.

${ }^{32}$ Eusebius, HE IV 22, 2-3, SCh 31, 199-200, POK 3, 178-179 (ze zmianami).

33 Por. A. Lumpe, Zur Hegesippsproblem, „Byzantinische Forschungen” 3 (1968) 165-167; H. Klemer, Hegesipps römische Bischofliste, VigChr 25 (1971) 182-196; L. Abramowski, Diadoché und orthoi logoi bei Hegesipp, ZKG 87 (1976) 321-327. 
Dalej, warto również podkreślić, iż fakt poszukiwania list sukcesyjnych, wiąże już wyraźnie kwestię prymatu z biskupami Rzymu, a nie tylko z Kościołem rzymskim. Czy jednak oznacza to rzeczywiście przyznanie biskupowi w Rzymie pierwszeństwa w przekazywaniu nauki apostolskiej? Świadectwo Hegezypa nie potwierdza oczywiście żadnego prymatu jurysdykcyjnego biskupa rzymskiego nad innymi wspólnotami, a prawowierność i czystość wiary apostolskiej została przechowana, jak sam podkreśla, również w Kościele korynckim oraz w „każdej sukcesji” apostolskiej i w „każdym mieście”, to zdaje się on traktować biskupów rzymskich jako uprzywilejowanych świadków nauczania apostolskiego. Pamiętajmy ciągle, że kontekst wypowiedzi jest wyraźnie antygnostycki. Hegezyp przeciwstawia gnostykom publiczną tradycję apostolską, która przetrwała w Kościołach założonych przez apostołów, w Rzymie przynajmniej na równi z innymi Kościołami. Jednak fakt, że, jak sam przyznaje, ustalił całą listę sukcesyjną biskupów tylko w Kościele rzymskim, zdaje się wskazywać na to, że traktował apostolską sukcesję rzymską jako uprzywilejowaną. Ireneusz piszący mniej więcej w tym samym czasie potwierdza:

„Ponieważ jednak wyliczanie sukcesji wszystkich Kościołów zajęłoby w niniejszym dziele zbyt wiele miejsca, przeto wskazując na następstwa największego i najstarszego, i wszystkim znanego, przez dwu najchwalebniejszych apostołów Piotra i Pawła założonego i ustanowionego w Rzymie Kościoła, który posiada tradycję apostolów i wiarę opowiadaną ludziom, a dochodzącą aż do nas drogą kolejnego następstwa biskupów, zawstydzamy tych wszystkich, którzy w jakikolwiek sposób, ale nie tak jak trzeba, gromadza koło siebie zwolenników, czy to dla swego upodobania, czy dla próżnej chwały, czy zaślepienia, czy też fałszywych przekonań" ${ }^{34}$.

Nie można wykluczyć, że Hegezyp myślał podobnie, choć nie wyraził tego wyraźnie w swoim tekście.

3. Tertulian. Kolejnym autorem chrześcijańskim, który podobnie jak Hegezyp, polemizował z gnostykami, był Tertulian. Apologeta afrykański na wzór Ireneusza $z$ Lyonu przekonywał, że tylko w Kościołach założonych przez apostołów przetrwała prawdziwa tradycja apostolska, gwarant prawdziwej nauki. Ta nauka była głoszona przez Apostołów publicznie wszystkim, a nie, jak twierdzą heretycy, w sposób sekretny tylko niektórym uczniom ${ }^{35}$. W jego Preskrypcji przeciw heretykom czytamy ${ }^{36}$ :

${ }^{34}$ Adversus haereses III 3, 2, SCh 211, 32-34.

35 Por. De praescriptione haereticorum 21, 1; 22, 3-4.

36 Por. J. Stimimann, Die Praescriptio Tertullians im Lichte des römisches Rechtes und der Theologie, Freiburg 1949, 45nn.; D. Michaelidas, Foi, écritures et tradition ou les „praescriptiones” chez Tertullien, Paris 1969; M. Wellstein, Nova verba in Tertullians Schriften gegen die Häretiker aus montanistischer Zeit, Stuttgart 1999, 45-98. 
„Chcesz dostatecznie zaspokoić ciekawość w sprawach zbawienia, przebiegnij więc Kościoły apostolskie, gdzie dotychczas siedziby Apostołów przewodniczą jeszcze na swoich miejscach i gdzie czyta się ich autentyczne pisma. Jeśli jesteś blisko Achai, masz Korynt, niedaleko Macedonii, masz Filippi i Tesalonikę, jeśli udasz się do Azji, masz Efez, jeśli jesteś w pobliżu Italii, masz Rzym, którego autorytet służy nam również za oparcie. O jak szczęśliwy to Kościół! Wraz ze swoją krwią Apostołowie przelali do niego calą swoją naukę. Tam Piotr poniósł śmierć podobną do Pana, a Paweł skazany na śmierć podobną do śmierci Jana, zaś Jan zanurzony w oleju ognistym nic nie ucierpiał i został zesłany na wyspe"

Tertulian, podobnie zresztą jak Ireneusz, stara się uzasadnić, że prawdziwa tradycja apostolska przetrwała tylko w Kościołach założonych przez Apostołów, takich jak Korynt, Filippi, Tesalonika, Efez i Rzym. Apologeta z Kartaginy podkreśla, co prawda, fakt męczeńskiej śmierci Piotra w Rzymie, i dosyć enigmatycznie mówi o równej śmierci Pawła $z$ Janem, wydaje się jednak, że traktuje Kościół w Rzymie jako świadka nauki apostolskiej równorzędnego $\mathrm{z}$ innymi Kościołami apostolskimi. Dla Zachodu, Cesarstwa i Afryki Północnej, to właśnie ten Kościół był jedynym przekazicielem tradycji apostolskiej. Schatz podkreśla, że Tertulian pisząc o Rzymie „porzuca trzeźwy język i wypowiada się w formie hymnicznej. Kościół rzymski zdaje się być otoczony szczególnym nimbem, bądź cieszy się swoistym poważaniem. Jest to jego powszechne, duchowe znaczenie, które nadaje mu szczególną miarodajność w określaniu prawdziwej wiary"38. W wyżej przytoczonym tekście Tertulian ma jednak na myśli raczej' cały Kościól, który najpełniej przekazuje właśnie prawdziwą naukę poprzez Kościoły założone przez Apostołów. Kościół w Rzymie nie zajmuje jednak w tym tekście pierwszeństwa, lecz na równi $z$ innymi jest przekazicielem tradycji apostolskiej.

W innym miejscu De praescriptione haereticorum $(23,1-3)$ Tertulian odpiera zarzuty gnostyków, że św. Paweł upominając Piotra w Antiochii zakwestionował jego autorytet i nauczanie w Kościele. Zdaniem gnostyków, upomnienie Pawłowe świadczyłoby o tym, że „czegoś brakowało” nauczaniu Piotra, a „pełniejsze poznanie zostało dane później Pawłowi, który upominał swoich

${ }^{37}$ De praescriptione haereticorum 36, 1-4, tłum. J. Czuj: Dowód z przedawnienia przeciw heretykom, CT 25 (1954) 229 (ze zmianami), tekst laciński ed. F. Refoulé, SCh 46, 136-138: „Age iam, qui voles curiositatem melius exercere in negotio salutis tuae, percurre ecclesias apostolicas apud quas ipsae adhuc cathedrae apostolorum suis locis praesident, apud quas ipsae authenticae litterae eorum recitantur sonantes vocem et repraesentantes faciem uniuscuisque. Proxima est tibi Achaia, habes Corinthum. Si non longe es a Macedonia, habes Philippos; si potes in Asiam tendere, habes Ephesum; si autem Italiae adiaces, habes Romam unde nobis quoque auctoritas praesto est. Ista quam felix ecclesia cui totam doctrinam apostoli cum sanguine suo profuderunt, ubi Petrus passioni dominicae adaequatur, ubi Paulus Ioannis exitu coronatur, ubi apostolus Ioannes posteaquam in oleum igneum demersus nihil passus est, in insulam relegatur".

${ }^{38}$ Schatz, Prymat papieski, s. 27; Seweryniak, Swiadectwo i sens, s. 455-456; B. Studer, Papato, DPAC II 2638-2642. 
poprzedników". Apologeta z Kartaginy wykazuje, że Paweł w swoim nauczaniu nie dodaje nic nowego do nauczania swoich poprzedników, a sam udaje się do Jerozolimy, by poddać swoje nauczanie ocenie autorytetów Kościoła. Tekst jednak wprost nie odnosi się do prymatu Kościoła czy biskupa Rzymu, ale do Piotra jako wiernego przekaziciela tradycji apostolskiej. Podobnie w De praescriptione haereticorum 32, 1-2 nasz apologeta uzasadnia, że tradycja apostolska przekazywana jest dzięki następcom Apostołów, ustanowionych przez nich samych. Jako przykład podaje Kościól w Smyrnie, ,który pamięta, że Polikarp został ustanowiony przez Jana i w Rzymie, gdzie Klemens został wyświęcony przez Piotra" ${ }^{39}$. Znowu jednak Kościół rzymski traktowany jest w tym fragmencie jako jeden z Kościołów apostolskich bez specjalnego uprzywilejowania.

Wiele kontrowersji budzą natomiast wypowiedzi Tertuliana z De pudicitia. Traktat ten, jak wiadomo, powstał w tzw. okresie montanistycznym jego życia, charakteryzującym się rygoryzmem moralnym. Tekst ten jest ważny dla historii dyscypliny penitencjalnej Kościoła, w którym przyznawał jedynie tzw. duchowej hierarchii, tzn. apostołom i prorokom władzę odpuszczania grzechów zabójstwa, apostazji i cudzołóstwa, a odmawiał ją późniejszej hierarchii kościelnej. Pismo polemizuje z tzw. edictum peremptorium wydanym przez jakiegoś biskupa, którego tożsamość pozostaje bardzo trudna do ustalenia. W De pudicitia bowiem czytamy:

„Adversus hanc (tzn. wstydliwości - podkreślenie moje) nunc, ne dissimulare potuissem, audio etiam edictum esse propositum, et quidem peremptorium. Pontifex scilicet maximus, episcopus episcoporum, edicit: «Ego et moechiae et fornicationis delicta paenitentia functis dimitto" $"$.

Na podstawie Philosophumena Hipolita ${ }^{41}$ badacze zidentyfikowali autora tego edyktu jako papieża Kaliksta (217-222). Jeśli tak, to tytuły, jakimi Tertulian określa biskupa Rzymu: pontifex maximus i episcopus episcoporum potwierdzałyby jego wyjątkową pozycją w całym Kościele, a sam edykt dowodziłby jego najwyższego autorytetu w kwestach praktyki penitencjalnej. Nie wiemy jednak do końca, czy Hipolit i Tertulian pisali o tych samych kwestiach i czy Tertulian miał rzeczywiście na myśli biskupa Rzymu. Współcześni badacze skałaniają się raczej ku hipotezie, że pisali oni o różnych kontrowersjach i z różnych powodów, a Tertulian odniósł zarówno pogański tytuł pontifex maximus, jak też biblijny episcopus episcoporum na sposób ironiczny do biskupa Kartaginy Agrypina ${ }^{42}$. Zdaniem Tertuliana, biskup Kartaginy uzurpowałby sobie prawo do stosowania innej praktyki pokutnej wobec grzeszników

39 De praescriptione haereticorum $32,2, \mathrm{SCh} 46,131$.

40 De pudicitia 6, 6, SCh 394, 146.

41 Por. Philosophumena IX 12.

42 Por. Quasten, Patrologia, s. 482 i 551; C. Micaelli, Introduction, SCh 394, 15nn. 
niż to było dotychczas praktykowane. Dlatego tytuły pontifex maximus i episcopus episcoporum miałyby w jego przekonaniu podkreślić w sposób ironiczny właśnie uzurpatorską postawę Agrypina. Tak np. określa Cyprian, biskup Kartaginy, kilkadziesiąt lat później pewnego aroganckiego chrześcijanina ${ }^{43}$. Podobnie rzecz miałaby się $\mathbf{z}$ innymi tytułami, obecnymi $\mathbf{w}$ traktacie, jak: bonus pastor et benedictus papa ${ }^{44}$. J. Quasten przekonuje, że odnoszą się one również do Agrypina, gdyż nie były w tym okresie znane jako tytuły specyficzne biskupa Rzymu. Argument ten jest jednak dosyć słaby, jeśli pamiętamy o zdolności Tertuliana do wymyślania neologizmów chrześcijańskich. Nie można również wykluczyć, że Tertulian byłby pierwszym świadkiem takiego określania biskupa Rzymu w II lub na początku III wieku. Kwestia pozostaje więc otwarta.

Trzeci fragment naszego traktatu jest jeszcze bardziej skomplikowany. Czytamy bowiem w nim:

"De tua nunc sententia quaero, unde hoc ius ecclesiae usurpes. Si quia dixerit Petro Dominus: «Super hanc petram aedificabo ecclesiam meam, tibi dabo claves regni caelestis», vel «Quaecumque alligaveris vel solveris in terra, erunt alligata vel soluta in caelis», idcirco praesumis et ad te derivasse solvendi et alligandi potestatem, id est ad omnem ecclesiam Petri provinciam, qualis es, evertens atque commutans manifestam Domini intentionem personaliter hoc Petro conferentem?" ${ }^{45}$.

Najwięcej kontrowersji wzbudził zwrot „ad omnem ecclesiam Petri provinciam", który w starszych wydaniach traktatu brzmial: „ad omnem ecclesiam Petri propinuam". Ch. Munier w nowym wydaniu "Sources Chrétiennes" zmienił „propinquam” na „provinciam” opierając się na rekonstrukcji G. Papona $^{46}$. Zasadnicze pytanie związane $z$ rozumieniem tego zwrotu brzmi: „omnis ecclesia Petri propinqua" odnosi się do Kościoła w Rzymie czy też do Kościoła powszechnego? C. Micaelli i J. Quasten podkreślają, że zwrot „ad omnem ecclesiam Petri propinuam" ma sens tylko wtedy, jeśli nie zostaje odniesiony do Kościoła rzymskiego, ale do wszelkiego Kościoła związanego $z$ Piotrem przez wiarę i pochodzenie ${ }^{47}$. Nie ma wątpliwości co do takiej interpretacji zwrotu, lecz rzeczywisty problem jest inny. Do kogo odnosi się cała ta wypowiedź: do Kaliksta czy biskupa Kartaginy? Przeciwnik Tertuliana musial powoływać się na cytat Mt 16,18, gdyż on również cytuje ten fragment ograniczając jednak potestas solvendi et alligandi nadaną przez Chrystusa Piotrowi tylko do niego samego, nie zaś do jego następców. Fakt odwołania się do Mt 16,

${ }^{43}$ Por. Epistola 66, 3.

44 Por. De pudicitia 13, 7, SCh 394, 208.

45 Tamże 21, 9-10, SCh 394, 272.

46 Por. Micaelli, Introduction, SCh 394, 31-38.

47 Por. Quasten, Patrologia, s. 551; Micaelli, Introduction, SCh 394, 30. 
18 mógłby wskazywać, że chodzi o biskupa Rzymu, następcę św. Piotra, lecz niekoniecznie. Tekst można rozumieć nadal dwojako, i na dwie zasadnicze grupy dzielą się badacze traktatu De pudicitia. Zdaniem jednych, biskup Kartaginy sądzi, że cytat z Mt 16,18 dowodzi, iż potestas solvendi et alligandi została nadana Piotrowi, a przez niego całemu Kościołowi, czyli równiez jemu. Taka interpretacja uznaje biskupa Kartaginy jako adresata traktatu. Inni z kolei sądzą, że potestas solvendi et alligandi została nadana Piotrowi i jego następcom, a przez nich całemu Kościołowi. Drugie rozumienie oznaczałoby, że Kalikst jako następca św. Piotra uznaje za swoją Piotrową potestas solvendi et alligandi $w$ Kościele. W konsekwencji więc, w naszej refleksji nad prymatem biskupa Rzymu w II wieku, tekst Tertuliana potwierdzałby władzę biskupa Rzymu w ostatecznym rozstrzyganiu kwestii spornych dotyczących praktyki pokutnej w tym okresie. Na obecnym etapie badań nad traktatem De pudicitia, brakuje jednak elementów, które umożliwiałyby ostateczne rozstrzygnięcie tej kwestii.

\section{SAMOSWIADOMOŚC ODPOWIEDZIALNOSCI KOŚCIOŁA/BISKUPA RZYMSKIEGO ZA KOŚCIÓŁ POWSZECHNY}

Równolegle do tekstów wczesnochrześcijańskich powstałych w I i w II wieku, które potwierdzają odnoszenie w mniej lub bardziej wyraźny sposób prymatu do Kościoła lub biskupa rzymskiego, pojawiają się źródła opisujące inicjatywy samego Kościoła lub biskupa rzymskiego, jako wyraz troski o inne Kościoły. Pierwszym i najstarszym tekstem w tym względzie jest List do Koryntian Kościoła w Rzymie, przypisywany Klemensowi. Ponieważ był on już analizowany wcześniej, więc tutaj zostanie pominięty. Późniejsze jednak spory, tzn. zarówno kontrowersja dotycząca daty celebracji Paschy w II wieku, jak też kolejna, pomiędzy Cyprianem z Kartaginy a Stefanem, łącząca się z kwestią ważności chrztu udzielanego przez heretyków, spotyka się $\mathrm{z}$ bardzo dużym oporem lokalnych biskupów w nie zaangażowanych ${ }^{48}$. Kościół i biskup rzymski nie są w stanie narzucić innym Kościołom swoich przekonań i praktyk. Wydarzenia te potwierdzają $z$ jednej strony samoświadomość wzrastającej troski ze strony Kościoła lub biskupa rzymskiego o inne Kościoły, natomiast $z$ drugiej, opór, jaki stawiają inne Kościoły wobec tego typu interwencji. $Z$ tego nie musi wcale wynikać, że inne Kościoły odrzucały zupełnie pierwszeństwo Kościoła lub biskupa rzymskiego, ale że były przeciwne takiej właśnie formie jego sprawowania. Przyjrzyjmy się więc teraz dokładniej kontrowersji związanej $z$ datą celebracji Paschy.

${ }^{48}$ Por. Schatz, Prymat papieski, s. 30. 
1. Kontrowersje dotyczące daty celebracji Paschy w II wieku. Kontrowersja dotycząca daty celebracji Paschy w II wieku związana była z dwiema różnymi tradycjami istniejącymi w Kościele tamtej epoki. Kwartodecymanie (od łac. quartus decimus) trzymali się żydowskiej praktyki celebrowania Paschy 14 dnia pierwszej wiosennej pełni księżyca, tj. 14 nisan bez względu na przypadający dzień tygodnia, natomiast druga tradycja przenosiła celebrację na niedzielę po 14 nisan. Często łączy się zwyczaj niedzielnej celebracji z wpływami pogańskimi nawiązując do świadectwa Justyna ${ }^{49}$, który w I Apologii (67) wyraźnie opisuje celebrację Eucharystii w tzw. Dies solis (dniu słońca). Trzeba jednak pamiętać, że opis Justyna dotyczy celebracji Eucharystii niedzielnej, a nie Paschy. Do tej ostatniej nawiązuje nasz apologeta w innym miejscu tejże Apologii (65), a tam nie ma już wzmianki o tym, że Pascha była celebrowana w niedzielę $e^{50}$. Chrześcijańska praktyka celebracji Paschy w pierwszą niedzielę po 14 nisan nie była spowodowana chrystianizacją pogańskiego kultu słońca, ale raczej odwołaniem się do dnia zmartwychwstania Chrystusa „pierwszego dnia po szabacie". W kalendarzu sadycejskim ten pierwszy dzień po szabacie był dniem składnia ofiar z pierwocin i stąd chrześcijańska celebracja zmartwychwstania Chrystusa była również świętowaniem pierwocin Jego nowego życia. W każdym razie do poł. II wieku obydwa zwyczaje były traktowane jako pochodzące od apostołów i godne praktykowania ${ }^{51}$. Euzebiusz tak oto opisuje rodzącą się kontrowersję:

„Podniesiono wtedy kwestię sporną niemałego znaczenia. Otóż Kościoły całej Azji sądziły, jak im się zdawało na podstawie bardzo starej tradycji, że święto Paschy Zbawiciela należy obchodzić 14 dnia księżyca, kiedy Żydzi mieli rozkaz ofiarowania baranka, i że w każdym razie tego dnia bez względu na to, jaki to byłby dzień w tygodniu, należy zakończyć posty. Tymczasem tego sposobu nie trzymały się wszystkie inne Kościoły całego świata, ale na mocy tradycji apostolskiej, która po dziś dzień swej mocy nie straciła, zachowywały zwyczaj, zee nie godzi się kończyć postów żadnego innego dnia, jak tylko w dniu zmartwychwstania naszego Zbawiciela. W sprawie tej odbyły się synody i zgromadzenia biskupów, którzy wszyscy jednomyślnie ogłosili listami do wiernych całego świata zasadę kościelną, że nigdy żadnego innego dnia nie należy obchodzić tajemnicy zmartwychwstania Pańskiego, jak tylko w niedzielę, i że tylko tego dnia wolno kończyć posty paschalne" ${ }^{\text {\$2 }}$.

Euzebiusz dodaje ponadto, że w jego czasach znane były pisma biskupów Palestyny, Teofila i Narcyza, biskupa Rzymu Wiktora, biskupów Pontu, którym przewodzi Palmas, Ireneusza z Galii, biskupów z Osroeny i wreszcie Bak-

${ }^{49}$ Tak twierdzi choćby K. Schatz (Prymat papieski, s. 30).

50 Por. 1 Apologia 65-67, thum. L. Misiarczyk, w: Pierwsi apologeci greccy, BOK 24, Kraków 2004, 254 wraz z przypisami i wstępem.

${ }^{51}$ Por. R. Cantalamessa, La Pasqua della nostra salvezza, tlum. M. Brzezinka: Pascha naszego zbawienia. Kraków 1998, 115-126.

52 Eusebius, HE V 23, 1-2, SCh 41, 66-67, POK 3, 237-238 (ze zmianami). 
chilosa, biskupa Koryntu oraz wielu innych (w tym Kościoła w Aleksandrii) wyznających tę samą zasadę ${ }^{53}$. Wyżej cytowany tekst zawiera jednak kilka ważnych elementów, które warto tutaj przywołać. Po pierwsze, Kościoły w Azji Mniejszej celebrujące Paschę 14 nisan powoływały się na bardzo starą tradycję apostolską. Po drugie, w ich celebracji Paschy chrześcijańskiej dominowało podkreślenie charakteru ofiarniczego śmierci krzyżowej Chrystusa korespondującej $\mathrm{z}$ momentem żydowskiej ofiary baranka paschalnego, i po trzecie - post przedpaschalny, kończył się dnia 14 nisan bez względu na to, jakikolwiek był to dzień. Zauważmy, że za tą praktyką stoi nie tylko jakieś sztywne trzymanie się zwyczaju żydowskiego, ale inna teologia chrześcijańskiej celebracji Paschy. Krótko mówiąc, kwartodecymanie odwoływali się do chronologii i teologii Jana Apostoła, który jako jedyny z ewangelistów umieszcza śmierć Jezusa na krzyżu w momencie zabijania na ofiarę baranka paschalnego w świątyni jerozolimskiej, a ich celebracja Paschy była bardziej celebracją ofiary śmierci Chrystusa jako nowego baranka paschalnego niż Jego zmartwychwstania ${ }^{54}$. Inne natomiast Kościoły, jak podkreśla Euzebiusz, również na mocy tradycji apostolskiej, były zdania, że nie godzi się kończyć postu w innym czasie, niż w dniu zmartwychwstania Pana. Jak widać, innym Kościołom chodziło raczej o przepisy czy zasady dotyczące zakończenia postu, niż jakiś ważny spór teologiczny. Problematyczne jest również stwierdzenie Euzebiusza, że tylko za zwyczajem niedzielnym stoi autorytet tradycji apostolskiej, natomiast za Kościołami Azji nie. Musiał przecież wiedzieć, że stał za nimi autorytet Jana Apostoła. Kościoły Janowe akcentowałyby więc w celebracji Paschy bardziej teologiczne rozumienie śmierci Jezusa jako ofiary nowego baranka paschalnego, natomiast pozostałe wspólnoty kwestię zasad postu. Odnosi się wrażenie, że starło się tu ze sobą teologiczne rozumienie Paschy, jako ofiary przez Kościoły Janowe $z$ podejściem raczej jurydycznym (posty) innych Kościołów.

Pierwsze wzmianki o dysputach związanych $\mathrm{z}$ datą celebracji Paschy pojawiają się w związku z wizytą Polikarpa, biskupa Smyrny w Rzymie ok. 154 r., gdzie z Anicetem (154-166) dyskutował o różnych kwestiach dotyczących życia Kościoła. Ireneusz w Liście do Wiktora, przekazanym przez Euzebiusza, opisał nam to spotkanie:

„Gdy zaś za czasów Aniceta błogoslawiony Polikarp przebywał w Rzymie, i gdy między nimi zaszło nieporozumienie $w$ innych sprawach niewielkiego znaczenia,

${ }^{53}$ Por. tamże, V 23, 3; 25.

54 Por. F.E. Brigtam, The Quartodecimn question, JTS 15 (1924) 254-270; C.C. Richardson, The Quartodecimns and the synoptic chronology, HTR 23 (1940) 177-190; B. Lohse, Das Passafest der Quartadecimaner, Gütersloh 1953; W. Huber, Passa und Ostern. Untersuchungen zur Osterfeier der alten Kirche, Berlin 1969; V. Loi, Quartodecimani, DPAC II 2963-2964; J. Gliściński, Wczesnochrześcijańska kontrowersja paschalna do czasów Soboru Nicejskiego, „Saeculum Christianum” 1 (1994) nr 1, 43-54. 
doszło wkrótce do zupełnej zgody; w tej zaś głównej sprawie nie chcieli rozpoczynać sporu. Anicet bowiem nie zdołal skłonić Polikarpa do zarzucenia zwyczaju, jakiego zawsze przestrzegał razem z Janem, uczniem Pańskim, i z innymi apostolami, z którymi się spotykał. Ani również Polikarp nie przekonał Aniceta, który twierdził, że należy się trzymać zwyczaju prezbiterów, swych poprzedników. Mimo to zachowali jedność, a w kościele Anicet w dowód szacunku pozwolił Polikarpowi na sprawowanie Eucharystii. Rzecz więc jasna, że się rozstali w pokoju i w całym też Kościele był pokój między tymi, którzy ten zwyczaj zachowywali, a tymi, co go nie przestrzegali",55.

Ireneusz napisał swój list do Wiktora, by go przekonać, iż inna data celebracji Paschy nie jest wystarczającym powodem do tego, by odłączać od jedności całe Kościoły. Pokazuje, że kilkadziesiąt lat wcześniej Polikarp i Anicet nawet nie podjęli się rozstrzygnięcia tej kwestii i nie mieli zamiaru ujednolicać praktyki celebracji Paschy, lecz każdy Kościół pozostał przy swoim zwyczaju, rzymski przy niedzieli, a smyrneński przy 14 nisan. Ireneusz zresztą w innym miejscu wyraźnie podkreśla, iż jest miejsce w Kościele na różnorodność nie burzącą jedności w tym, co istotne. Dla nas jednak inna informacja w Liście Ireneusza jest bardzo ważna: podkreśla on mianowicie, że Polikarp, a $\mathrm{z}$ nim inne Kościoły Azji celebrując Paschę 14 nisan trzymają się tradycji Jana i innych apostołów, natomiast Anicet tradycji „prezbiterów, swoich poprzedników”. Autorytet apostolski stoi więc, zdaniem biskupa Lyonu, nie tylko za praktyką niedzielnej celebracji Paschy, przekazanej przez starszych Kościoła rzymskiego, ale również za kwartodecymanami. Wraz z Polikarpem zwyczaj celebracji Paschy 14 nisan praktykowali w II wieku i inni biskupi Azji Mniejszej, jak Meliton z Sardes i Apolinary z Hierapolis. Różnica ta nie przeszkadzała jednak w zachowaniu wspólnoty jedności pomiędzy Polikarpem i Anicetem. Byłoby rzeczą niezmiernie ciekawą dowiedzieć się, kiedy w Rzymie ukształtowała się praktyka celebracji Paschy w niedzielę po 14 nisan, lecz niestety nie znajdziemy na ten temat żadnej wzmianki w źródłach wczesnochrześcijańskich.

Zanim przejdziemy dalej, warto zatrzymać się jeszcze nad jednym wątkiem obecnym w tekstach Euzebiusza. Niektórzy uczeni w oparciu o Ireneuszowy List do Wiktora wysunęli przypuszczenie, że Kościołem w Rzymie kierowało początkowo kolegium prezbiterów, a nie jeden biskup, zaś episkopat monarchiczny w Rzymie pojawiłby się dopiero w 2. poł. II wieku. Nic jednak nie upoważnia nas do takiego wniosku. Sam przecież Ireneusz właśnie w Liście do Wiktora wyraźnie określa biskupów Rzymu, poprzedników Sotera, prezbiterami:

„wśród nich byli także prezbiterzy, którzy przed Soterem stali na czele Kościoła przez Ciebie obecnie rządzonego, a więc Anicet, Pius. Hygin, Telesfor Ksystus [...] owszem, prezbiterzy, poprzednicy Twoi, którzy się sami tego zwyczaju (tj. daty

${ }^{55}$ Eusebius, HE V 24, 16-17, SCh 41, 71, POK 3, 242 (z niewielkimi zmianami). 
celebracji 14 nisan - nawias mój l.m.) nie trzymali, posyłali Eucharystię wiernym Kościolów zwyczaj zachowujących" ${ }^{\text {"6 }}$.

Z tego tekstu wynika wyraźnie, że Ireneusz określa prezbiterami poszczególnych biskupów Rzymu, poprzedników Wiktora. Wiemy natomiast, iż w Listach Ignacego Antiocheńskiego termin „prezbiter” oznaczał określony stopień w hierarchii kościelnej. Jak widać termin „prezbiter” miał różne znaczenie w tekstach chrześcijańskich II wieku. Używano go najprawdopodobniej zarówno w sensie szerokim na określenie wszystkich członków hierarchii kościelnej, na pewno biskupów Rzymu (Ireneusz) oraz w sensie wąskim jako drugi stopień w hierarchii kościelnej po biskupach, a przed diakonami (Ignacy).

Kontrowersja odżywa pod koniec II wieku, najprawdopodobniej ok. 195 r., gdy Kościołem w Rzymie kierował Wiktor (189-198), który zagroził ekskomuniką, wyłączeniem z jedności kościelnej tych, którzy nie przyjmują zwyczaju rzymskiego obchodzenia Wielkanocy w niedzielę po 14 nisan. Czym należy tłumaczyć tak radyklanie odmienną postawę Wiktora? Niektórzy badacze sugerują, iż to $z$ powodu wspomianego przez Euzebiusza niejakiego Blasto$\mathrm{sa}^{57}$, który miałby wprowadzać w Rzymie praktyki kwartodecyman, ale tekst Euzebiusza nie mówi wprost, iż w przypadku Blastosa chodziło rzeczywiście o datę celebracji Paschy. Radykalizm Wiktora spowodowany był najprawdopodobniej przybyciem do Rzymu licznej rzeszy chrześcijan z Azji Mniejszej, którzy celebrowali Paschę 14 nisan oraz pościli w inne dni, niż chrześcijanie rzymscy. Wywołalo to niemałe zamieszanie i biskup Rzymu starał się ujednolicić praktykę, co z kolei wywołało sprzeciw kwartodecyman. Najprawdopodobniej na wniosek Wiktora zwoływane zostały w tej sprawie synody lokalne w Palestynie, Italii, Galii, Poncie i Azji Mniejszej. Polikrates, biskup Efezu, zaznacza bardzo wyraźnie na końcu swojego Listu do Wiktora i Kościoła rzymskiego, że zwołał biskupów właśnie na jego polecenie:
„Mógłbym wymienić biskupów razem ze mną tutaj obecnych, których zwołania żądaliście ode mnie i których też zwołałem. Gdybym wypisał ich imiona, byłoby ich bardzo wiele. Wiedzą oni, że jestem czlowiek mały, a przecież zatwierdzili moje pismo, bo wiedzą, że nie na próżno noszę siwiznę, ale że zawsze żyłem w Chrystusie Jezusie" ${ }^{\text {"58. }}$.

Tekst ten jest najstarszym śladem inicjatwy ze strony biskupa Rzymu, dotyczącej odpowiedzialności za Kościół powszechny. Ciekawe, że wszystkie synody, łącznie z Kościołem aleksandryjskim opowiadają się za niedzielną celebracją Paschy $z$ wyjątkiem Kościołów w Azji Mniejszej. Wiktor zapewne przypomniał

\footnotetext{
56 Tamże, V 24, 14-15, SCh 41, 70-71, POK 3, 242.

57 Por. tamże, V 15; V 20, 1.

58 Tamże, V 24, 8, SCh 41, 69, POK 3, 241 (z niewielkimi zmianami).
} 
wszystkim, że tradycja rzymska, oparta na świadectwie Piotra i Pawła, ma znaczenie wyjątkowe, ale, i warto to podkreślić, nie narzuca praktyki celebracji niedzielnej swoją decyzją odgórną, lecz poleca zwołanie w tej sprawie synodów lokalnych. Polikrates zwołuje synod w Azji Mniejszej i przesyła podjętą decyzję Wiktorowi we wspomnianym już wcześniej Liście do Wiktora i Kościola rzymskiego, przekazanym przez Euzebiusza:

„My tego dnia nie święcimy lekkomyślnie; nic nie dodajemy i nic nie ujmujemy. Albowiem w Azji wielkie zaszły gwiazdy, które wzejdą w dniu przyjścia Pańskiego, kiedy $z$ niebios przyjdzie w chwale i wzbudzi wszystkich swiętych, Filipa, jednego z dwunastu apostołów spoczywającego w Hierapolis [...]. Jest jeszcze Jan, który spoczywał na piersi Pana. Nosił on jako kapłan diadem, męczennik i nauczyciel, a spoczywa w Efezie. Dalej Polikarp w Smyrnie, biskup i męczennik, Traksas, biskup i męczennik z Eumenei, który spoczywa w Smyrnie. A czy trzeba wymieniać Sargisa, biskupa i męczennika, który spoczywa w Laodycei albo błogosławionego Papiriosa i Melitona rzezańca, który całe swoje życie był pełen Ducha Świętego, a spoczywa w Sardes czekając nawiedzenia niebios, kiedy powstanie z martwych. Ci wszyscy przestrzegali czternastego dnia Paschy według Ewangelii i w niczym od tego nie odstąpili, ale szli zawsze za regułą wiary. Tak i ja, Polikrates, najmniejszy spośród Was wszystkich idę za tradycją moich krewnych, a po niektórych biorę następstwo [...]. I zawsze krewni moi ten dzień święcili, którego naród wstrzymywał się od kwasu. Tedy ja, bracia, który żyję w Panu 75 lat, spotykalem się $\mathrm{z}$ braćmi całego świata $\mathrm{i}$ dokładnie wczytałem się $\mathrm{w}$ cale Pismo św., nie boję się pogróżek albowiem więksi ode mnie powiedzieli «Należy więcej stuchać Boga aniżeli ludzi»"

Polikrates powołuje się wyraźnie na tradycję apostolską, przekazaną przez św. Jana i Filipa, oraz swoich poprzedników, którzy świętowali Paschę 14 nisan, a także podkreśla, iż nie lęka się żadnych pogróżek. Najwidoczniej Wiktor polecając mu zwołanie synodu Kościołów w Azji Mniejszej już wtedy grozil im karą ekskomuniki, jeśli nie przyjmą zwyczaju rzymskiego. Na tak stanowczy opór ze strony biskupów z Azji Mniejszej Wiktor zapewne nie liczył i, jak napisał Euzebiusz „występuje z zamiarem odcięcia od wspólnej jedności wszystkich gmin azjatyckich oraz Kościołów sąsiednich, jak gdyby były innowiercze, i ogłasza publicznie na piśmie, że wszyscy bez wyjątku tamtejsi bracia są wyłączeni z jedności" ${ }^{\prime 60}$. Nie podobało się to jednak wszystkim biskupom, którzy zwrócili się do niego z upomnieniem, by starał się „o pokój, jedność i miłość bliźniego". Euzebiusz przytacza wypowiedź w tym względzie Ireneusza z Lyonu, który, choć nie podzielał zwyczaju kwartodecyman, to jednak nie uznawał tego za wystarczający powód do odłączania ich od jedności wiary. Zdaniem Ireneusza, spór dotyczy nie tylko dnia celebracji, ale również różnych praktyk postu, jednak w przeszłości „wszyscy mimo to żyli w pokoju i my

59 Tamże, V 24, 2-7, SCh 41, 67-69, POK 3, 239-240 (z niewielkimi zmianami).

60 Tamże, V 24, 9, SCh 41, 69, POK 3, 241. 
jedni z drugimi żyjmy w pokoju, a różnica w poście potwierdza tylko jedność wiary" "61. Przypomina także Wiktorowi, że jego poprzednicy Anicet, Pius, Hygin, Telesfor, Sykstus, Soter ,ani sami takiego zwyczaju (tj. celebracji Paschy 14 nisan - nawias mój) nie zachowywali, ani na to swoim podwładnym nie pozwalali, a jednak [...] zyli mimo to $w$ pokoju $z$ wiernymi, którzy do nich przychodzili z Kościołów, gdzie taki zwyczaj istniał [...]. I nigdy nie zdarzyło się, by $z$ tego powodu ktokolwiek miał być wykluczony, owszem, prezbiterzy, poprzednicy twoi, którzy się sami tego zwyczaju nie trzymali, posyłali Eucharystię wiernym Kościołów zwyczaj ten zachowujących"62. Udział we wspólnej Eucharystii, podobnie jak w przypadku spotkania Polikarpa z Anicetem kilkadziesiąt lat wcześniej, był traktowany jako znak jedności wiary.

Choć nie wiemy, jak tak naprawdę zakończyła się ostatecznie ta kontrowersja, to jednak wydaje się, że Ireneuszowi udało się chyba ostatecznie przekonać Wiktora, gdyż nieznana nam jest żadna dłuższa schizma $\mathrm{z}$ tego okresu. Groźby Wiktora pozostały, na szczęście, prawdopodobnie tylko groźbami. Późniejsi autorzy chrześcijańscy, jak Hipolit Rzymski ${ }^{63}$, Ps-Tertulian ${ }^{64}$, Epifaniusz $^{65}$, czy Teodoret z Cyru ${ }^{66}$, zaliczają kwartodecyman do heretyków. Decyzja Soboru Nicejskiego, nakazująca wszystkim Kościołom chrześcijańskim celebrację Paschy w pierwszą niedzielę po 14 nisan, marginalizuje jeszcze bardziej praktykę kwartodecyman, która przetrwa w niektórych wspólnotach chrześcijaństwa wschodniego aż do czasów Epifaniusza ${ }^{67}$.

$Z$ punktu widzenia naszej refleksji nad kształtem prymatu Kościoła lub biskupa Rzymu, kontrowersja ta ukazuje nam dwie bardzo ważne rzeczy: Biskup Rzymu czuje się odpowiedzialny za cały Kościół powszechny i podejmuje inicjatywy z nią związane, tzn. nakazuje zwołanie synodów; po drugie, nikt nie kwestionuje jego prawa do przewodzenia Kościołowi powszechnemu. Dyskusja toczy się jedynie wokół pytania o formę tego przewodzenia. Opór Polikratesa i biskupów Azji Mniejszej oraz upomnienia innych biskupów na czele z Ireneuszem nie podważają pierwszeństwa Wiktora, lecz raczej zachęcają go do takiej odpowiedzialności za cały Kościół, która uwzględnia różnorodność praktyk postu i daty celebracji Paschy. Ireneusz zdaje się wręcz przestrzegać, że zbytnie szafowanie ekskomuniką w mniej ważnych sprawach jest drogą do nikąd. Czy próbę narzucenia przez Wiktora całemu Kościołowi praktyki niedzielnej celebracji Paschy należy uznać za przejaw prymatu jurysdykcji

61 Tamże, V 24, 13, SCh 41, 70, POK 3, 241-242.

62 Tamże, V 24, 14-15, SCh 41, 70-71, POK 3, 242.

${ }^{63}$ Por. Philosophumena VIII 18.

${ }^{64}$ Por. Adversus omnes haereses 8, 1.

65 Por. Panarion 50, 1.

66 Por. Haereticarum fabularum compendium III 4.

67 Por. Loi, Quartodecimani, DPAC II 2964; Gliściński, Wczesnochrześcijańska kontrowersja paschalna, s. 43-54. 
biskupa Rzymu? Czy pierwszeństwo to rozumiano wcześniej na zasadzie prymatu jurysdykcji czy też Wiktor nadał mu taką właśnie nową formę? Warto niewątpliwie zauważyć, że w kontekście różnych praktyk tylko biskup Rzymu jest świadom odpowiedzialności za jednolitość praktyk liturgicznych i upoważniony do podjęcia interwencji w tym celu, nie zaś inne Kościoły zalożone przez apostołów. On poleca zwołanie w tym celu synodów lokalnych, i Polikrates z Efezu jest mu w tym posłuszny. Nie narzuca jednak niczego bezpośrednio, lecz jego interwencja jest zapośredniczona w synodach lokalnych. Pierwszeństwo Kościoła i biskupa Rzymu w II wieku nie polegało na prymacie jurysdykcji w dzisiejszym rozumieniu, lecz z pewnością było posługą na rzecz jedności całego Kościoła. Nie tylko w Rzymie celebrowano w II wieku Paschę w niedzielę, ale jak potwierdza Euzebiusz, również w Palestynie, Poncie i Aleksandrii. Nie byłoby to więc w sensie ścisłym narzucanie innym zwyczaju rzymskiego, lecz próba ujednolicenia praktyki celebracji w całym Kościele. Sprzeciw Kościołów Azji Mniejszej potwierdza, iż w sposobie sprawowania prymatu biskupa Rzymu w II wieku widziały one możliwość przeciwstawienia się jego decyzji w sprawie praktyki celebracji Paschy, opartej na tradycji św. Jana Apostoła. Z drugiej jednak strony, fakt, że Wiktor chce ekskomunikować Kościoły kwartodecyman wskazuje, iż w świadomości innych miał do tego prawo, którego zresztą nikt nie podważa. Ireneusza przekonuje Wiktora, że nie warto stosować ekskomuniki, ale nie kwestionuje jego prawa do niej. Może to stanowić dowód na to, że mamy tutaj do czynienia $z$ najstarszym świadectwem samoświadomości biskupa Rzymu co do odpowiedzialności jurysdykcyjnej za cały Kościól. Wiktor czyni to poprzez nakaz zwołania synodów lokalnych i groźbę eksomuniki Kościołów w Azji Mniejszej.

$* * *$

W podsumowaniu podkreślmy, że pierwszeństwo w Kościele starożytnym związane było $\mathrm{z}$ wyborem do tej misji Piotra przez samego Chrystusa. Wraz z nim prymat "wędrował" z Jerozolimy (por. Sobór Jerozolimski) przez Antiochię do Rzymu, miejsca męczeńskiej śmierci Piotra. ${ }^{68} \mathrm{O}$ ile sama idea pierwszeństwa Piotra w Kościele obecna w Nowym Testamencie budzi stosunkowo mało wątpliwości, o tyle pytanie o prymat jego następców na stolicy biskupiej w Rzymie oraz formę jego sprawowania jest już zdecydowanie trudniejsze. W refleksji nad prymatem Kościoła czy biskupa Rzymu w II wieku konieczne jest odróżnienie odnoszenia prymatu przez inne Kościoły do Kościoła lub biskupa Rzymu od samoświadomości prymacjalnej samego Kościoła lub biskupa Rzymu. W II wieku pierwszeństwo do Kościoła lub biskupa Rzymu odnoszą Ignacy z Antiochii, Hegezyp i Tertulian, natomiast List do Koryntian

${ }^{68}$ Por. R.E. Brown - J.P. Meier, Antioche et Rome, Paris 1988, 257-262. 
Klemensa Rzymskiego i kontrowersje związane $z$ datą celebracji Paschy, są wyrazem kształtującej się stopniowo samoświadomości prymacjalnej Kościoła i biskupa Rzymu.

Ignacy nie odnosi przewodzenia do biskupa Rzymu, ale do Kościoła w Rzymie i rozumie je jako przewodzenie duchowe i religijne całemu Kościołowi powszechnemu. Niewykluczone, że dotyczyło spraw wiary i obyczajów, i wtedy nasz tekst byłby rzeczywiście świadectwem prymatu Kościoła w Rzymie (jeszcze nie biskupa) w sprawach wiary i obyczajów. Brakuje jednak elementów, które pozwoliłyby takie rozumienie przewodzenia ostatecznie potwierdzić lub wykluczyć. Być może na to świadectwo trzeba by spojrzeć przez pryzmat $\mathbf{J}$ 21 i pytania Chrystusa do Piotra o większą miłość. Ignacy mając w pamięci ten tekst Janowy określiłby Kościół w Rzymie jako powołany na wzór Piotra do większej miłości Pana niż pozostałe Kościoły. Jest natomiast mało prawdopodobne, by Ignacy odnosił określenie Kościoła w Rzymie jako „przewodzącego miłości" w sensie prymatu jurysdykcyjnego nad całym Kościołem.

W podobnym tonie brzmi świadectwo Hegezypa. Nie przypisuje on, co prawda, biskupowi rzymskiemu żadnego prymatu jurysdykcyjnego nad innymi wspólnotami i podkreśla, że prawowierność i czystość wiary apostolskiej została przechowana w „każdej sukcesji” apostolskiej i w „każdym mieście”, to jednak fakt, że, jak sam przyznaje, ustalił całą listę sukcesyjną biskupów tylko w Kościele rzymskim, zdaje się wskazywać na to, że traktował apostolską sukcesję rzymską jako uprzywilejowaną w przekazywaniu nauczania apostolskiego.

Tertulian w De praescriptione haereticorum traktuje Kościół w Rzymie jako przekaziciela tradycji apostolskiej na równi $z$ innymi Kościołami, nie przedstawia go jednak jako mającego pierwszeństwo. Fragmenty z De pudicitia dotyczą sporu o praktykę pokutną i władzę Kościoła nad tzw. grzechami nieodpuszczalnymi (zabójstwo, cudzołóstwo, apostazja). Przeciwnik Tertuliana powołuje się na potestas solvendi et alligandi przekazaną przez Chrystusa Piotrowi, a poprzez niego całemu Kościołowi. Badacze pism Tertuliana są jednak podzieleni w interpretacji tych fragmentów: jedni odnoszą je do papieża Kaliksta, inni natomiast do biskupa Kartaginy Agrypina. Jeśli De pudicitia byłoby adresowane do Kaliksta i jego autorstwa byłby słynny edykt polecający odpuszczać grzechy nieczyste, to byłoby to jedno $z$ najstarszych świadectw sprawowania wyraźnej władzy jurysdykcyjnej biskupa Rzymu nad całym Kościołem. Kwestia ta jest jednak nadal jeszcze żywo dyskutowana.

W kontekście sporu związanego z datą celebracji Paschy w II wieku zapowiedź papieża Wiktora ekskomunikowania wspólnoty chrześcijańskiej w Azji Mniejszej byłaby najstarszym pewnym świadectwem samoświadomości odpowiedzialności jurysdykcyjnej Biskupa Rzymu za Kościół powszechny. Ta odpowiedzialność jurysdykcyjna byłaby oczywiście inna, niż w dzisiejszym rozumieniu, ale warto podkreślić, iż nikt nie odmawiał Wiktorowi prawa do 
nakazania zwolania synodów lokalnych $w$ tej sprawie oraz odłączenia od jedności Kościoła chrześcijan z Azji Mniejszej. Ireneusz radził tylko, że nie warto tego czynić.

\section{IL PRIMATO DELLA CHIESA O DI VESCOVO DI ROMA NELLE FONTI CRISTIANE DEL SECOLO II}

(Sommario)

Nella riflessione sul primato della Chiesa o del Vescovo di Roma nel II secolo è necessario distinguere il fatto di riferire il primato da altre communità ecclesiastiche di allora alla Chiesa o al Vescovo di Roma dalla consapevolezza del primato della stessa Chiesa di Roma o dei suoi Vescovi. Nel II secolo, come ci è stato trasmesso dalle fonti cristiane antiche, il primato veniva riferito alla Chiesa o al Vescovo di Roma da Ignazio di Antiochia, Egesippo e Tertuliano, invece Lettera ai Corinzi di Clemente e la controversia riguardante la data della celebrazione di Pasqua testimoniano appunto la crescente consapevolezza del primato nella Chiesa e nei Vescovi di Roma.

Ignazio di Antiochia nella sua Lettera ai Romani riferisce la presidenza alla Chiesa di Roma (non al Vescovo) e la intende come la presidenza nella vita spirituale e religiosa di tutta la Chiesa. Non si può escludere che questa comprendeva anche le questioni di fede e dei costumi cristiani, e se fosse proprio così, il nostro testo testimonierebbe l'esistenza del primato della Chiesa di Roma (non del Vescovo) nell'insegnamento della fede e dei costumi. Ci mancano peró i dati per confernare o rifiutare ulterioremente una tale ipotesi. Ho proposto quindi di rileggere la testimonianza di Ignazio alla luce del Vangelo di Giovanni 21 con le famose domande di Gesù a Pietro sull'amore più grande. Non è completamente da scartare l'ipotesi che Ignazio avendo in mente questo testo giovanneo avesse descritto la Chiesa di Roma come chiamata all'amore più grande per il Signore di tutte le altre Chiese.

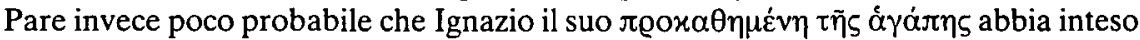
nel senso del primato di giurisidizione della Chiesa di Roma sulla Chiesa universale.

Egesippo, pur riportando la lista delle successioni dei vescovi ,in ogni città" come completa cita soltanto quella dei vescovi di Roma. Questo fatto indica che egli considerava la succesione dei vescovi romani come lugo privileggiato per la trasmissione della tradizione apostolica.

Tertuliano nel De praescriptione haereticorum tratta la Chiesa di Roma come trasmittore della tradizione apostolica uguale ad altre chiese e non la vede come superiore o in qualche modo privileggiata. Invece il frammento del trattato $D e$ pudicitia che riguarada la discussione sul potere della Chiesa sui peccati irremisibili (omicidio, adulterio, apostasia) è molto più complicato. L'avversario a cui Tertuliano si rivolge con questo testo si riferiva alla potestas solvendi et alligandi conferita da 
Cristo a Pietro e attraverso lui a tutta la Chiesa. Non è facile però rispondere alla domanda chi fosse l'autore del famoso editto perentorio. Alcuni studiosi sono del parere che si tratta del papa Callisto, altri che del vescovo di Cartagine Agrippino. Se l'editto fosse stato quello del papa Callisto allora avremmo qui una delle più antiche testimonianze del primato di giurisidizione del Vescovo di Roma sulla Chiesa universale in materia della prassi penitenziale. La questione tuttavia rimane per ora ancora molto discussa.

Nel contesto della controversia sulla data della celebrazione di Pasqua l'annuncio del papa Vittore di voler scomunicare le chiese di Asia Minore sarebbe la più antica e sicura testimonianza della consapevolezza di una responsabilità giuridica del Vescovo di Roma sulla Chiesa universale. Non si tratta ovviamente della resposnabilità giuridica intesa nel senso odierno, ma merita di essere sottolineato il fatto che nessuno dei vescovi d'allora mette in discussione il diritto di Vittore di scomunicare i cristiani di Asia Minore. S. Ireneo, grande vescovo di Lione soltanto glielo sconsiglia. 